\title{
World Trade in Medicinal Plants from Spanish America, 1717-1815
}

\author{
STEFANIE GÄNGER* \\ University of Cologne, Department of Iberian and Latin American History, \\ Albertus-Magnus-Platz, 50923 Cologne, Germany
}

\begin{abstract}
This article outlines the history of the commerce in medicinal plants and plant-based remedies from the Spanish American territories in the eighteenth century. It maps the routes used to transport the plants from Spanish America to Europe and, along the arteries of European commerce, colonialism and proselytism, into societies across the Americas, Asia and Africa. Inquiring into the causes of the global 'spread' of American remedies, it argues that medicinal plants like ipecacuanha, guaiacum, sarsaparilla, jalap root and cinchona moved with relative ease into Parisian medicine chests, Moroccan court pharmacies and Manila dispensaries alike, because of their 'exotic' charisma, the force of centuries-old medical habits, and the increasingly measurable effectiveness of many of these plants by the late eighteenth century. Ultimately and primarily, however, it was because the disease environments of these widely separated places, their medical systems and materia medica had long become entangled by the eighteenth century.
\end{abstract}

Keywords: Colonial Spanish America, Medicinal plants, Drug trade, Global history of medicine, Economic botany

Had you entered the storehouse of Spain's Royal Pharmacy in Madrid sometime in the late eighteenth century, you could have seen one of the world's richest and most complete collections of medicinal plants extracted from the crown's American possessions - plants that were 'known and trafficked' around the world at the time. The shelf just above the stairway through which you arrived would have held Peruvian calaguala, contrayerva then hailed as an antidote - and several chests of mechoacán, a mild purgative - renamed jalap root by the colonists for its abundance in the Xalapa region. There would also have been cases holding the brittle resin of copal, as well as covered pitchers enclosing black and white 'Peruvian balsam' and Maria Oil balsam, both exudations from the trunk of trees that were administered in wound treatments and chest ailments. ${ }^{1}$ Had you looked across

* Email address for correspondence: sgaenger@uni-koeln.de

An earlier version of this paper was presented at the Conference 'Transfer of Knowledge in the Iberian Colonial World', held at the Max Planck Institute for the History of Science in Berlin, 4-6 September 2013. I would like to thank Jürgen Renn and Helge Wendt for convening this event, and them and the other participants - in particular José Pardo-Tomás, Timothy D. Walker, Elaine Leong and Nuria Valverde - for their comments and suggestions.

1 'Lista de lo que contiene el estante de Almazen que esta encima de la entrada de la escalera de la cueva, [List of the Contents of the Shelf in the Storeroom Opposite the Stairway of the Cave]' Archivo del Palacio Real, Caja 22282 (Madrid, 1783-06-12). 
the room, you could have seen another, larger shelf just opposite the entrance, holding tins of liquidambar, another balsam, a jar of coconut oil and Campeche amber. ${ }^{2} \mathrm{Had}$ you walked on, you would have encountered more quarters, with more shelves, holding boxes with the wood and resin of palo santo - the Spanish term for guaiacum - and sarsaparilla root, a Honduran and Jamaican species of smilax, both of them long hailed as anti-syphilitics, with chests of curled cinnamon bark and the greens of canchalagua, a 'blood purifier'. You might have recognised tamarinds, then employed as a purgative, tabasco pepper, then both spice and stimulant, and vanilla pods, then both flavour and aphrodisiac. Had you paced a little further, you could have seen that the bark of cinchona trees, 'highly celebrated for its effects against intermittent fevers' at the time - diagnosed retrospectively as a form of malaria - filled a storeroom of its own, where large wooden chests with hundreds of kilograms of fine, dried chippings of the bark were stacked, one on top of the other. ${ }^{3}$ Had you been able to slip into yet another room, you might have had a glimpse of chests of canafistola, the nuts of the castor oil plant, the bark and wood of sassafras - a sudorific - or of jugs holding balsam of Tolu, copaiba balsam or 'fine dragon blood' - the red resin of Croton trees - and ipecacuanha, the dried root of cephaelis trees, valued for its effectiveness against dysentery and as an emetic. ${ }^{4}$ Perhaps you might have been fortunate enough to pass by at the very moment the contents of some of these chests were unpacked, to be arranged with the extant holdings. Then you might have seen that letters from naturalists and officials in the harvest areas or Spanish American ports had been attached to each jug and chest with an 'account of their content and its utility' for peninsular pharmacists, indicating the remedy's geographical origin, the source of the senders' knowledge about it and instructions on how to prepare, administer or apply it. ${ }^{5}$

Madrid's Royal Pharmacy, founded in the sixteenth century to cater for the health of the monarch and his family and court, certainly had privileged access to medicinal plants and plant-based remedies from the crown's American possessions. However, these same remedies were to be found in medicine chests, pharmacies and medical provisions all over Europe, in the Americas, and even beyond in the eighteenth century. ${ }^{6}$ Medicinal plants

2 'Razón de los Generos que existen en el Almazen de la Quina. Lista de lo que contiene el estante alto del Almazen de enfrente entrando, [Account of the Medicines Held in the Cinchona Storehouse. List of the Contents of the Upper Shelf Opposite the Entrance of the Storeroom]' Archivo del Palacio Real, Caja 22282 (1783-06-16).

${ }^{3}$ See, for instance, Joseph Martínez Toledano, 'Orden para que se custodie en el Almazen la Quina existente, [Order to Keep the Cinchona in Stock in the Storeroom]' Archivo del Palacio Real, Caja 22282/Expediente Número 6 (Madrid, 1772).

4 The 'Razón de los Generos Medicinales que producen nuestras Américas' recorded the plants kept in the Royal Pharmacy, quantified the holdings, specified their medically active parts - usually bark, sap or root and detailed their acceptance in medicine, from the most popular substances to some that were only 'of little use' (de poco uso): 'Razón de los Generos Medicinales que producen nuestras Américas, y que para el ahorro de la Real Hacienda combendria se mandasen benir para la serbidumbre de la Real Botica, [Account of the Medicines Produced in our Americas, which for the Convenience of the Royal Treasury should be Sent to the Royal Pharmacy]' Archivo General de Indias, Indiferente 1547 (Madrid). Lists of medicinal substances imported from Honduras and the viceroyalties of Peru and Mexico confirm and complement this list. 'Memoria de generos medicinales del Reyno del Peru y Provincias immediatas, [Inventory of Medicines from the Viceroyalty of Peru and its Surrounding Provinces]' Archivo General de Indias, Indiferente 1552 (1745-09-30); 'Memoria de Generos para la Botica del Rey que se crian en Mexico y Provincias, y Islas convezinas a el, [Inventory of Medicines for the Royal Pharmacy that Grow in Mexico and its Provinces and Neighboring Islands]' Archivo General de Indias, Indiferente 1552 (Buen Retiro, 1746-11-24).

${ }^{5}$ María Esther Alegre Pérez, 'La Real Botica y las especies americanas (siglo XVIII), [The Royal Pharmacy and its American Drugs]' Boletín de la Sociedad Española de Historia de la Farmacia, XXXV, 140 (1984), $225-43$.

${ }^{6}$ On the history of Madrid's Royal Pharmacy and its holdings of American medicinal plants, see José Luis Valverde, 'El comercio de drogas americanas en el siglo XVIII y el aprovisionamiento de la Real Botica, [The Commerce in American Drugs in the Eighteenth Century and the Provisioning of the Royal Pharmacy]' Anales de la Real Academia de Farmacia, 49 (1983), 309-34; Alegre Pérez, op. cit. (note 5). 
and plant-based remedies from the Spanish American territories were conveyed around the world at the time: sarsaparilla and cinchona, ipecacuanha and jalap root were almost as much sought after, as much haggled over and as much exported as America's silver, its emeralds and its tobacco. While Iberian trade in precious metals, gemstones or stimulants has attracted considerable scholarly attention in recent years, ${ }^{7}$ the history of the commerce in medicinal plants from the Spanish American territories in the eighteenth century is, as Jorge Cañizares-Esguerra put it not too long ago, 'yet to be written'. ${ }^{8}$ This article is an advance into the history of trade in medicinal plants and plant-based remedies from Spain's colonial territories in the Americas, from the early years of Bourbon rule to 1815, when the last Manila galleon sailed from Acapulco. Relying heavily on and, at the same time, canvassing, extant literature on the history of economic and medical botany in the Spanish empire, ${ }^{9}$ this article, in the first part, provides data on which plants were chosen for trade, on the quantities shipped and on the routes - to Europe and, along the arteries of European commerce, colonialism and proselytism, into North America, Asia and Africa. In its second part, the article enquires into the causes of - the driving forces behind the plants' geographically and socially far-ranging 'mobility'. The language of 'liquidity' so prevalent in research on the 'circulation' of knowledge or the 'flow' of commodities

${ }^{7}$ On emeralds, see Kris Lane, Colour of Paradise: The Emerald in the Age of Gunpowder Empires (New Haven, CT and London: Yale University Press, 2010). Tobacco achieved a modest medical reputation but its popularity rested chiefly on its effects as a stimulant. On stimulants and silver, see in particular the vogue in the literature for 'commodity chains': Steven Topik, Carlos Marichal and Frank Zephyr, 'Commodity chains in theory and in Latin American history', in Steven Topik, Carlos Marichal and Frank Zephyr (eds), From Silver to Cocaine: Latin American Commodity Chains and the Building of the World Economy, 1500-2000 (Durham, NC and London: Duke University Press, 2007), 1-24.

8 Jorge Cañizares Esguerra, 'Iberian Colonial Science', Isis, 96 (2005), 67.

${ }^{9}$ Some aspects of botany in the Spanish empire - metropolitan expeditions, Creole scholars' patriotic impulses and the co-ordinated information-gathering through the empire's bureaucracies - have attracted considerable attention in recent years. Jorge Cañizares Esguerra, Nature, Empire, and Nation: Explorations of the History of Science in the Iberian World (Stanford, CA: Stanford University Press, 2006); Arndt Brendecke, Imperium und Empirie: Funktionen des Wissens in der spanischen Kolonialherrschaft [Empire and Empiricism. Functions of Knowledge in Iberian Colonial Rule] (Cologne, Weimar and Vienna: Böhlau, 2009); Daniela Bleichmar, 'Atlantic competitions: Botany in the eighteenth-century Spanish Empire', in James Delbourgo and Nicholas Dew (eds), Science and Empire in the Atlantic World (New York and London: Routledge, 2008), 225-54; Antonio Barrera-Osorio, Experiencing Nature: The Spanish American Empire and the Early Scientific Revolution (Austin: University of Texas Press, 2006). José Luis Valverde has made important inroads into the history of the trade in medicinal plants in relation to the Royal Pharmacy: Valverde, op. cit. (note 6). So have José María López Piñero and Mauricio Nieto Olarte: José María López Piñero and María Luz López Terrada, La influencia española en la introducción en Europa de las plantas americanas (1493-1623) [Spanish Influence on the Introduction of American Plants to Europe] (Valencia: Instituto de Estudios Documentales e Históricos sobre la Ciencia, 1997); María Luz López Terrada and José Pardo Tomás, 'Las primeras noticias y descripciones de las plantas americanas (1492-1553), [The first news and descriptions of American plants]', in José María López Piñero, et al. (ed.), Medicina, drogas y alimentos vegetales del Nuevo Mundo: Textos e imágenes españolas que los introdujeron en Europa (Madrid: Ministerio de Sanidad y Consumo, 1998), 19-103; Mauricio Nieto Olarte, Remedios para el imperio: Historia natural y la apropiación del nuevo mundo [Remedies for the Empire: Natural History and the Appropriation of the New World] (Bogotá: Instituto Colombiano de Antropología e Historia, 2000). Some of these medicinal plants, particularly cinchona and, to a lesser extent, guaiacum and ipecacuanha, have attracted the attention of scholars more particularly: Matthew James Crawford, 'Empire's Experts: The Politics of Knowledge in Spain's Royal Monopoly of Quina (1751-1808)' (unpublished PhD dissertation, University of California San Diego, 2009); Saul Jarcho, Quinine's Predecessor: Francesco Torti and the Early History of Cinchona, The Henry E. Sigerist Series in the History of Medicine (Baltimore, MD and London: Johns Hopkins University Press, 1993); Felicitas Söhner, Neue Welt und neuzeitliche Medizin: Guajakholz als Heilmittel und Handelsware [New World and Early Modern Medicine: Guaiacum as Remedy and Commodity] (Munich and Ravensburg: GRIN, 2008); M.R. Lee, 'Ipecacuanha: The South American Vomiting Root', Journal of the Royal College of Physicians of Edinburgh, 38 (2008), 355-60. 
today has tended to obscure the fact that the world has never been an even medium of transmission - that only very few of America's or, for that matter, the world's, natural products actually became globally consumed goods. ${ }^{10}$ It is worth querying why medicinal plants from Spanish America, and which of them precisely, appealed so broadly and found such ready acceptance among physicians and sufferers around the world.

\section{The Global Reach of Spanish American Medicinal Plants}

The exploitation of America's natural resources by the Spanish Crown reached its zenith under the rule of Charles III (1759-88): the magnitude and scale of commerce in American medicinal plants in the second half of the eighteenth century was unprecedented. ${ }^{11}$ While between 1717 and 1738 Spain had imported a total of 83387 arrobas of medicinal plants an average of 3970 arrobas or 45 tonnes per annum - by the second half of the eighteenth century that amount had tripled: between 1747 and 1778 a total of 418977 arrobas - 13515 arrobas or 155 tonnes every year - reached Cádiz, Spain's key port for the monopoly trade with the Americas in that period. ${ }^{12}$ While importations of medicinal plants multiplied over the eighteenth century, the variation between the first half of the eighteenth century and the earliest years of the trade in medicinal plants was negligible: some 36.8 tonnes of medicinal plants had been introduced into Spain per annum in the decades after $1568 .{ }^{13}$ While the overall import volume increased considerably over the course of the eighteenth century, the remedies that made up the bulk of the exports essentially remained the same throughout. Between 1717 and 1738, Spain's average annual imports comprised 24 tonnes of 'purges', 13 tonnes of cinchona, 5.6 tonnes of sarsaparilla, 2 tonnes of contrayerva, 1.6 tonnes of copal and 1 tonne of 'balsams'. By the second half of the eighteenth century, imports of purges, copal, balsams and contrayerva had tripled in weight, while cinchona imports showed a six-fold increase: between 1747 and 1778 Spain imported an annual average of 64 tonnes of 'purges', 83 tonnes of cinchona, 5 tonnes of copal, 3.9 tonnes of 'balsams' and 7kg of contrayerva. Only sarsaparilla had declined slightly, amounting then to 4 tonnes annually. ${ }^{14}$ Imports from the harbours of New Spain - Veracruz, Honduras and Campeche - reflect a similar development. Between 1689 and 1720, Spain's average annual imports comprised 5 tonnes of jalap root, 1.6 tonnes of sarsaparilla, $484 \mathrm{~kg}$ of cinchona, $452 \mathrm{~kg}$ of liquidambar, $290 \mathrm{~kg}$ of copal, $80 \mathrm{~kg}$ of contrayerva, $5 \mathrm{~kg}$ of canafistola, and $9 \mathrm{~kg}$ of Michoacán through Cádiz. ${ }^{15}$ A century later, by the year 1802 , New Spain exported thirteen times as much sarsaparilla - some 461 quintals or 21 tonnes - and twenty-seven times as much jalap root - 2921 quintals or 134 tonnes - as it had a

\footnotetext{
${ }^{10}$ For one recent critical discussion of the language of 'fluidity' prevalent in global history, see S.A. Rockefeller, 'Flow', Current Anthropology, 52, 4 (2011), 557-78.

${ }^{11}$ Historians of Iberian botany have often made that claim. Paula De Vos, 'Natural History and the Pursuit of Empire in Eighteenth-Century Spain', Eighteenth-Century Studies, 40, 2 (2007), 209-39.

12 Antonio García-Baquero González, Cádiz y el Atlantico (1717-1778) [Cadiz and the Atlantic], 2 vols, Vol. 1 (Cádiz: Diputación Provincial de Cádiz, 1988), 338.

13 Pierre Chaunu and Huguette Chaunu, Séville et l'Atlantique (1504-1650): Première Partie: Partie Statistique: Le Mouvement des navires et des marchandises entre l'Espagne et l'Amérique de 1504 à 1650 [Seville and the Atlantic: First Part: Statistics: The Movement of Ships and Merchandise Between Spain and America] (Paris: S.E.V.P.E.N., 1956), 1027-9.

14 García-Baquero González, op. cit. (note 12), Vol. 1, 340.

15 The totals over the space of 31 years amounted to over 170 tonnes of jalap root, 50 tonnes of sarsaparilla, 15 tonnes of cinchona, over 14 tonnes of liquidambar, 9 tonnes of copal, 2.5 tonnes of contrayerva, $149 \mathrm{~kg}$ of canafistola, and 276kg of Michoacán: Consolación Martínez García, Drogas importadas desde Nueva España (1689-1720) [Drugs Imported from New Spain] (Sevilla: University of Seville, 1991), 41.
} 
century earlier. ${ }^{16}$ New Spain's cinchona exports were negligible - in fact they decreased further over the century from $484 \mathrm{~kg}$ to $368 \mathrm{~kg}$ per annum - because the bulk of cinchona, harvested on the eastern slopes of the Andes, came to Cádiz from the Viceroyalty of Peru, whence it would have been shipped around Cape Horn. ${ }^{17}$ Like the commerce in other commodities, cinchona exports soared in the era of 'free trade' between 1778 and 1796, when other peninsular ports were allowed to trade with Spanish America. ${ }^{18}$ While between 1717 and 1738 Spain had only imported a total of some 24293 arrobas - 279 tonnes, some 13 per annum - of cinchona, ${ }^{19}$ more than 20000 arrobas or 230 tonnes were handled by Spanish merchants in 1788, some 438026 libras or 201 tonnes in 1789, some 15000 arrobas or 172.5 tonnes in 1791 and 250000 libras or 115 tonnes in 1794, the year of the first coalition's war against Revolutionary France in the eastern Pyrenees. $^{20}$

These official exports were probably a fraction of the actual amounts traded: Spain was not the only supplier of many of the medicinal plants that grew within its American possessions. Spain had a 'natural monopoly' over some medicinal plants - cinchona, canchalagua and Peruvian balsam - but others prospered also in Portuguese, Dutch, French and British American territories. The ipecacuanha in the Amazon and Atlantic forests was shared by Brazil and Paraguay, coconut oil and American cinnamon were found in the Dutch colonies of Surinam, Berbice and Essequibo in Guyana, ${ }^{21}$ and balsam of Tolu, wild cinnamon, the castor oil plant, contrayerva and tamarinds grew on the island of Jamaica. ${ }^{22}$ Spain's European competitors did not only market plants that thrived within their own colonial possessions. Though the exact routes and the volume of illegal trade in America's medicinal plants elude us - the difficulty of pursuing the plants onto a contrabandist's vessel or through the bustle of a marketplace render any mapping or quantification necessarily fragmentary - the paper trail in Spain's archives leaves little doubt that foreign merchants handled a significant volume of contraband and that Spain faced 'much difficulty' in closing the trade's many 'gateways and entries'. ${ }^{23}$ Theft of legal exports was common throughout the eighteenth century: Spanish pharmacists often complained that boxes with 'precious balsams' from 'the Indies' reached them half empty, with evident traces of having been opened 'in some other place' - with their nails removed and their leather clamps cut. ${ }^{24}$ The mass per unit volume of dried barks or powdered roots is very low - purges, balsams, sarsaparilla, copal, cinchona and contrayerva taken together amounted only to 3\% of Spain's total imports in weight between 1717 and 1738

16 Alexander von Humboldt, Ensayo político sobre el reino de la Nueva España [Political Essay on the Viceroyalty of New Spain], trans. Vicente Gonzalez Arnao, Vol. 4 (Paris: Rosa, 1822), 75.

17 On Spain's shipping routes, see García-Baquero González, op. cit. (note 12) Vol. 1, 275.

18 John Fisher, Commercial Relations Between Spain and Spanish America in the Era of Free Trade, Centre for Latin American Studies, The University of Liverpool (Manchester: Manchester Free Press, 1985), 70.

${ }^{19}$ García-Baquero González, op. cit. (note 12), Vol. 1, 336-51.

20 Juan Riera Palmero, 'Quina y malaria en la España del siglo XVIII, [Cinchona and Malaria in Spain in the Eighteenth Century]' Medicina \& Historia: Revista de estudios históricos de las ciencias médicas, 52 (1994), 21.

21 Robert A. DeFilipps, Shirley L. Maina, and Juliette Crepin, Medicinal Plants of the Guianas (Guyana, Surinam, French Guiana) (Washington, DC: National Museum of Natural History, 2004).

22 James Thomson, A Treatise on the Diseases of Negroes, as they Occur in the Island of Jamaica: With Observations on the Country Remedies (Jamaica: Aikman, 1820), 166-8.

23 'Expediente y cartas de José García de Leon y Pizarro, [Proceedings and Letters from José García de Leon y Pizarro]' Archivo General de Indias, Indiferente 1554 (1782-08-18).

${ }^{24}$ Alegre Pérez, op. cit. (note 5), 226. 
and to $2.45 \%$ between 1747 and $1778^{25}$ - making them an obvious target for smuggling. It would seem that Portuguese, British, Dutch and French merchants, overcoming the Spanish government's efforts to restrict trade with its colonies, even acquired medicinal plants directly from harvesters along America's coasts and at the stopovers along the plants' shipping routes. Spanish officials estimated in 1774 that even from the total volume of trade with cinchona, 'a plant that grows only in the dominions of His Majesty', Spanish merchants handled but 'one-sixth'. ${ }^{26}$ Spanish observers' estimates may have been a long guess but present-day historians of the harvest areas agree that the amount of illegally smuggled cinchona did surpass, and certainly was a multiple of, the volume of Spain's official trade in the bark. ${ }^{27}$ The exact scale of contraband in medicinal plants and plantbased remedies from the Spanish American territories may be elusive - its reality, however, is irrefutable.

The bulk of the Spanish American exports - both legal and illegal - went into the broader European markets. By the second half of the eighteenth century, American medicinal plants were part of the standard medical repertoire on the Iberian Peninsula, in France, the Netherlands, England, the territories of the Holy Roman Empire and the Italian peninsula. By this time, cinchona, sarsaparilla, jalap root, Peruvian balsam, guaiacum and ipecacuanha were among the basic supplies of pharmacies in Europe's cities. ${ }^{28} \mathrm{~A}$ vigorous regional drug trade - already firmly in place in much of eighteenth-century northern and western Europe by the eighteenth century - redistributed foreign remedies among consumers outside the urban centres. ${ }^{29}$ As early as the 1740 s, even a common

25 Sabine Anagnostou, Jesuiten in Spanisch-Amerika als Übermittler von heilkundlichem Wissen [The Jesuits as Mediators of Medicinal Knowledge in Spanish America], Vol. 78 (Stuttgart: Wissenschaftliche Verlagsgesellschaft, 2000), 276-80.

26 'Informe de la Contaduría de 9 de Julio de 1774 y respuesta del Sor Fiscal de 30 de Agosto del mismo año, [Report of the Accountant's Office from 9 July 1744 and Response from the Fiscal from 30 August of the Same Year]' Archivo General de Indias, Indiferente 1554 (Madrid, 1774-06-09), 835-6.

${ }^{27}$ Luz del Alba Moya, Auge y Crisis de la Cascarilla en la Audiencia de Quito, Siglo XVIII [The Cinchona Boom and Crisis in the Quito Audiencia, Eighteenth Century] (Quito: Latinoamericana de Ciencias Sociales, Sede Ecuador, 1994), 32-5.

28 On importations of 'American Remedies' for the Kingdom of the Two Sicilies, see Reisen durch Beide Sicilien [Journeys Across the Two Sicilies], trans. Johann Reinhold Forster (Hamburg: Carl Ernst Sohn, 1785). On Spanish American remedies in Europe's Jesuit pharmacies in Cologne, Munich, Oelde, Milan or Madrid, see Sabine Anagnostou, Missionspharmazie: Konzepte, Praxis, Organisation und wissenschaftliche Ausstrahlung [Missionary Pharmacy: Concepts, Practice, Organisation and Scientific Outreach], Sudhoffs Archiv. Zeitschrift für Wissenschaftsgeschichte. Beiheft (Stuttgart: Franz Steiner, 2011), 286-8. On the supplies of American remedies in a Leuven pharmacy, see 'Advertentie, [Advertisement]' Leeuwarder courant 14 March 1789. On importations of guaiacum, cinchona or sassafras into Russia, see Jarcho, Quinine's Predecessor: Francesco Torti and the Early History of Cinchona, 91. By the 1740s France was importing sassafras, Campeche wood, guaiacum, sarsaparilla, cinchona, balsam of Tolu, copaiba and Peru balsam, ipecacuanha, contrayerva, dragon blood, liquidambar and jalap root from the Spanish American territories. This list is taken from Jacques Savary des Bruslons, Dictionnaire universel de commerce [Universal Dictionary of Commerce] (Paris: Veuve Estienne et fils, 1748), 477. See also René Février, L'Importation des drogues d'Amérique en France sous l'ancien régime (1539-1789) en particulier par le port de Bordeaux [The Importation of Drugs from America into France under the Ancien Regime (1539-1789), in particular through the Port of Bordeaux] (Toulouse, Caffin, 1941), 43

29 On the drug trade in the regions of the Duchy of Brunswick in the eighteenth century, see Gabriele Beisswanger, Arzneimittelversorgung im 18. Jahrhundert: Die Stadt Braunschweig und die ländlichen Distrikte im Herzogtum Braunschweig-Wolfenbüttel [Pharmaceutical Supply in the Eighteenth Century: The City of Brunswick and Rural Districts in the Duchy of Brunswick-Wolfenbüttel] (Brunswick: Deutscher Apotheker, 1995). On England, see Steven King, 'Accessing drugs in the eighteenth-century regions', in Louise Hill Curth (ed.), From Physick to Pharmacology: Five Hundred Years of British Drug Retailing (Aldershot: Ashgate Publishing, 2006), 49-78. 
itinerant apothecary would have had some medicinal plants from Spanish America in stock: when the possessions of the barber-surgeon Pape in the village of Seesen in Lower Saxony were inventoried in 1742, for instance, it was found that he kept copaiba balsam, Peruvian balsam and jalap root among his provisions, and he could easily have procured cinchona, ipecacuanha or guaiacum from pharmacies in nearby Brunswick. ${ }^{30}$ As the late eighteenth-century upsurge in Spanish legal imports - and in accusations of smuggling - intimates, medicinal plants from Spanish America became available to an unprecedented number of patients at the time. In England, where even the most common imported drugs were only arriving in sufficient volume to treat a few thousand people in the late sixteenth century, there was a mass market for at least some imported drugs by the mid-eighteenth century. According to Patrick Wallis' calculations, an average of one dose of sarsaparilla per every two people was imported into England by that time. ${ }^{31}$ The same holds true for other Spanish American drugs and European medical markets. Physicians administered on average some $50 \mathrm{~g}$ of cinchona bark to effect a cure or, at least, give relief to the men and women suffering from endemic vivax malaria in Europe at the time ${ }^{32}$ - the vast majority of them living around the North Sea basin, in the brackish coastal zones of Flanders, the Baltic, eastern and southern England, Normandy and Friesland. ${ }^{33}$ Around 1750, when Europe had a population of 71.7 million, Spain's legally imported 83 tonnes alone would have been sufficient for some 1.7 million cases of malaria, then $2.3 \%$ of the European population, every year. By the end of the century, annual imports having almost tripled, cinchona could have reached up to some five million people. Assuming Europe's overall importations of cinchona were a multiple - even if only a two- or threefold one - of legal imports, they converge toward the ratio Wallis has found for England's sarsaparilla consumption. ${ }^{34}$ The share of American medicinal plants in pharmacies, family medicine chests or the provisions of barber-surgeons would still have been modest in relation to home-grown plants from the village herb woman or the kitchen garden in Europe. ${ }^{35}$ However, it was by all accounts equal to that of remedies coming from other distant places, like South or East Asia. An inventory of the plant-based remedies kept at the Hôtel-Dieu de Carpentras in southern France in the late eighteenth century, for instance, documents that about half of its remedies were 'homegrown', Mediterranean plants, while the other half came from abroad: some $28 \%$ from the

\footnotetext{
${ }^{30}$ Beisswanger, op. cit. (note 29), 260-70.

${ }^{31}$ Patrick Wallis, 'Exotic Drugs and English Medicine: England's Drug Trade, c.1550-c.1800', Social History of Medicine, 25, 1 (2011), 34.

32 William Buchan, the author of some of the period's most popular medical advice, advised a dose of 'two ounces of the bark Peruvian bark, finely powdered' to 'cure an ague' in 1774. William Buchan, Domestic Medicine, or, A Treatise on the Prevention and Cure of Diseases (London: W. Strahan, 1774), 167.

33 On European malaria, see L.W. Hackett, Malaria in Europe: An Ecological Study (London: Oxford University Press, 1937; repr. 1944); Huibert Arius van Seventer, The Disappearance of Malaria in the Netherlands (Amsterdam: Foddegan, 1969); Leonard Jan Bruce-Chwatt and Julian de Zulueta, The Rise and Fall of Malaria in Europe (Oxford: Oxford University Press, 1980); Lena Huldén, Larry Huldén and Kari Heliövaara, 'Endemic Malaria: An 'Indoor' Disease in Northern Europe: Historical Data Analysed', Malaria Journal, 4, 19 (2005), 1-13.

34 Wallis, op. cit. (note 31), 33-4.

35 On the limited - though steady - influence in Portugal of drugs, remedies and medical techniques from Asia in the eighteenth century, see Timothy Walker, 'Remedies from the Carreira da Índia: Asian Influences on Portuguese Medicine during the Age of Enlightenment', Portuguese Studies Review, 9, 1-2 (2001), 170-93. For England, see Elaine Leong, 'Making Medicines in the Early Modern Household', Bulletin of the History of Medicine, 82, 1 (2008), 145-68.
} 
contiguous Levant, 11\% from the territories bounding the Indian Ocean and another 11\% from the 'New World'. 36

Medicinal plants were widely available within the Americas, too, traded from their natural habitat across the Spanish possessions and to the British and French North American markets. New England apothecaries, Louisiana hospitals and plantation medicine chests in the antebellum south of the United States of America invariably included ipecacuanha, jalap root and cinchona, ${ }^{37}$ and sometimes sarsaparilla or guaiacum. ${ }^{38}$ By 1809 , the United States directly imported from the port of La Guaira in Venezuela guaiacum, bags of cinchona bark and copal, and flasks of copaiba balsam. ${ }^{39}$ In about 1820 in the British colony of Jamaica, plantation medicine chests catering to the needs of both masters and slaves included imported and home-grown plants in proportions similar to those seen in the provisions of the Hôtel-Dieu in Carpentras. A Jamaican standard medicine chest contained some thirty remedies that had been 'produced in the country' and about forty-three needing 'to be imported'; $15 \%$ of all the remedies contained were plant-based medicines from the Americas. ${ }^{40}$ There was also a vibrant market for medicinal plants within the Spanish American territories: Spanish imperial trade routes took medicinal plants from South America to the Viceroyalty of New Spain and back, ${ }^{41}$ while the pharmaceutical networks of the Society of Jesus redistributed plantbased remedies through the viceroyalty of Peru and across the border with Portugal's American territories. ${ }^{42}$ According to the 1748 report of the Lima Jesuit Juan Francisco Toro, cinchona, guaiacum, ipecacuanha, contrayerva, calaguala and Peruvian balsam were among the most commonly used remedies in the practice of medicine in Peru. ${ }^{43}$ Drug trading in the regions was vibrant in Spanish America, too, where several of these plants would have been sold for a fraction of the price they cost in Europe or its other colonies. In the early nineteenth century an ambulant apothecary and barber-surgeon like Nicolás Brenes from the city of Cartago in Costa Rica could sell - much like his Lower-Saxon

36 Colette Dubois, 'Le Quotidien d'une pharmacie hospitaliere: La Boutique de l'Hôtel-Dieu de Carpentras, [Everyday Life in a Hospital Pharmacy: The Provisions of the Hôtel-Dieu de Carpentras]', in G.J. Aillaud (ed.), Herbes, Drogues et Epices en Mediterranée (Paris: CNRS 1988), 90.

${ }^{37}$ Norman Gevitz, "'Pray let the medicines be good": The New England apothecary in the seventeenth and early eighteenth centuries', in Gregory J. Higby and Elaine C. Stroud (eds), Apothecaries and the Drug Trade: Essays in Celebration of the Work of David L. Cowen (Madison, WI: American Institute of the History of Pharmacy, 2001), 15; Sharla M. Fett, Working Cures: Healing, Health, and Power on Southern Slave Plantations (Chapel Hill, NC and London: University of North Carolina Press, 2002), 68.

38 'Colonie de la Loüisianne, [Louisiana Colony]' Archivo del Palacio Real.

39 Jacques A. Barbier and Allan J. Kuethe, The North American Role in the Spanish Imperial Economy: 17601819 (Manchester: Manchester University Press, 1984), 167.

${ }^{40}$ From England, Jamaicans imported patent medicines and chemical compounds like cream of tartar, vitriolic ether and Glauber's salts; from Asia or the Levant, myrrh, camphor and rhubarb; from South America, cinchona, ipecacuanha, and jalap. The remainder of American plants all prospered on the island of Jamaica. Thomson, op. cit. (note 22), 166-8.

${ }^{41}$ Eduardo Arcila Farias, Comercio entre Venezuela y Mexico en los siglos XVII y XVIII [Commerce between Venezuela and Mexico in the Seventeenth and Eighteenth Centuries] (Mexico City: El Colegio de Mexico, 1950).

42 The Jesuit pharmacy of San Pablo College in Lima was a particularly important distribution centre for American plant-based remedies. Luis Martin, The Intellectual Conquest of Peru: The Jesuit College of San Pablo, 1568-1767 (New York: Fordham University, 1968). See also Anagnostou, op. cit. (note 28), 327.

43 José Luis Valverde, Evaluation of Latin American Materia Medica and its Influence on Therapeutics (Granada: International Academy of History of Pharmacy, 2010), 154. 
contemporary - South American medicinal plants ranging from ipecacuanha to copal to customers along his way. ${ }^{44}$

Plant-based remedies from the Spanish American territories went into Europe's colonial possessions and accompanied their expansion. By the late eighteenth century, ship's surgeons in the British Navy and the Dutch East India Company alike were routinely provided with medical chests containing potions and herbs, with their curative properties noted on prescribed lists: next to calomel, opium and mercury, the chests infallibly contained cinchona, ipecacuanha, copaiba balsams, guaiacum, powdered jalap and sarsaparilla. ${ }^{45}$ José Pinto de Azeredo, a Brazilian doctor appointed surgeon general of Portuguese Angola, was accustomed to administering ipecacuanha, cinchona and cinnamon waters in the merchant community of Luanda, West Africa's largest slaving port. ${ }^{46}$ Medicinal plants from Spanish America crossed the Pacific on the Manila Galleons, sailing from the port of Acapulco in Mexico to the Philippines, for the needs of the Spanish settler population and for redistribution within Asian commercial networks. Between 1772 and 1815, seven Manila galleons left Acapulco for Manila with freights of jalap root, cinchona powder and unprocessed bark, and Peruvian balsam. Three galleons left with freights of dragon blood, ten galleons left with the root, bark and leaves of sarsaparilla, and two left with the leaves and flowers of canchalagua and contrayerva. ${ }^{47}$ The majority of these remittances were derivatives - processed remedies such as oils, essences, powders or ointments rather than entire plants or their barks, roots and leaves ${ }^{48}$ - with American knowledge about their effective parts and preparation 'built into' them. The data we have on the weight or value of Spain's exports of plant-based remedies via the Manila galleons is vague, and it is very likely that Spain's Asian exports were negligible in comparison to its European ones. However, there apparently was a market for American medicinal plants and American medicinal knowledge in East Asia. ${ }^{49}$ The pharmaceutical networks of the Jesuit Order along the routes of Portuguese colonial expansion had earlier led to the inclusion of American medicinal plants in East Asian materia medica and prepared the ground for Spain's Asian exports. Recipes retrieved from the 1766 manuscript Colleccão de varias receitas e segredos particulares das principaes boticas da nossa Companhia de Portugal, da India, de Macáo e do Brasil - a 633 page manuscript compilation of medical recipes from Jesuit pharmacies in the Portuguese territories - document that Jesuit pharmacies in Macau, situated near the mouth of the Pearl River, as well as in

\footnotetext{
44 Nicolás Brenes's possessions were inventoried in 1850: Steven Palmer, Doctors, Healers, and Public Power in Costa Rica, 1800-1940 (Durham, NC and London: Duke University Press, 2003), 17-36.

45 Iris Bruijn, Ship's Surgeons of the Dutch East India Company: Commerce and the Progress of Medicine in the Eighteenth Century (Amsterdam: Amsterdam University Press, 2009), 350. On the role of the Dutch East Company in world trade in medicinal plants more broadly, see Harold J. Cook, Matters of Exchange: Commerce, Medicine and Science in the Age of Empire (Hyderabad: Orient Longman, 2008).

46 Jose Pinto de Azeredo, Ensaios sobre algumas enfermidades d'Angola [Essays on Some Diseases of Angola] (Lisbon: Na Regia Officina Typografica, 1799).

${ }^{47}$ Reyna María Pacheco Olivera, 'Análisis del intercambio de plantas entre México y Asia de los siglos XVI al XIX [Analysis of Plant Exchange between Mexico and Asia during the Sixteenth to Nineteenth Centuries]' (unpublished Master's thesis, National Autonomous University of Mexico, 2006), 192.

${ }^{48}$ Ibid.

49 Viceroy Antonio Caballero y Góngora repeatedly mentioned plans to increase Asian cinchona consumption 'through Acapulco and the Philippines' for the benefit of the Royal Treasury. Antonio Caballero y Góngora, 'Carta al Marquès de Sonora [Letter to the Marques de Sonora]', Archivo General de Indias, Indiferente 1554 (Santa Fé, 1786-10-19).
} 
Indian Goa, had long relied on American medicinal plants like cinchona, copaiba balsam, Michoacán and jalap root for their preparations. ${ }^{50}$

Along the routes of Iberian and Genoese, English, Dutch and French trade, America's medicinal plants were also sold in societies adjoining western Europe's colonial, commercial and evangelising entrepôts in Africa and Asia. Spanish American balsams and cinchona were among the few goods imported into Nagasaki, Japan's only governmentally sanctioned point of entry for foreign merchants, by the Dutch East Indies Company (VOC). Following the expulsion of the Portuguese in 1638, only Chinese merchants and representatives of the VOC were allowed to enter Japan to engage in trade, and the commodities brought to satisfy domestic demand were dictated by the - often quite explicit - requests and regulations emitted by the shogunate. ${ }^{51}$ Merchants from Marseille, Genoa and Great Britain re-sold medicinal plants from the Spanish American territories in the Ottoman Empire - much to the chagrin of the Spanish Empire, which was seeking to establish direct trade links with the Ottoman Empire at the time: ${ }^{52}$ Peruvian balsam, ipecacuanha, jalap, cinchona, sarsaparilla and sassafras from the Americas were available on the markets of Istanbul and Smyrna - today's Izmir - a cosmopolitan entrepôt provisioning Anatolia and the Syrian and Persian markets with produce from western Europe. ${ }^{53}$ The middling and upper strata of several Levantine societies valued Spanish America's medicinal plants. When the Sultan of Morocco, Mohammed Ben Abdellah al-Khatib, chose his gifts from the Spanish court in 1771 - Spain and Morocco were alternately making and breaking diplomatic arrangements between 1767 and the Aranjuez Convention in 1780, and gift exchange between Charles III and the Sultan was assiduous throughout - his list encompassed books about astronomy and globes but also a number of plant-based remedies from Spanish America the Sultan was apparently accustomed to using. These comprised jalap root, various balsams, ointments 'to reduce fleshiness' and 'to close wounds', cinchona, Maria Oil and several cordials. ${ }^{54}$ Following the timehonoured practice of gift-exchange in Eurasian diplomatic etiquette, under Charles III the Spanish court gave away hundreds of kilograms of remedies from the supplies of the

\footnotetext{
${ }^{50}$ On the Jesuit pharmacies of Goa and Macao, see Anagnostou, op. cit. (note 28), 284-5, 91-2. On Portuguese networks of commerce in plant-based remedies, see Timothy Walker, 'The Early Modern Globalization of Indian Medicine: Portuguese Dissemination of Drugs and Healing Techniques from South Asia on Four Continents, 1670-1830', Portuguese Literary \& Cultural Studies, 17/18 (2010), 77-97.

${ }^{51}$ See Martha Chaiklin, Cultural Commerce and Dutch Commercial Culture: The Influence of European Material Culture on Japan, 1700-1850 (Leiden: CNWS, 2003), 78-191. See also Robert Liss, 'Frontier tales: Tokugawa Japan in translation', in S. Schaffer, et al., The Brokered World: Go-Betweens and Global Intelligence, 17701820 (Sagamore Beach: Watson, 2009), 8.

52 On the attempts of Charles III to establish direct trade links with the Ottoman empire, see Hüseyin Serdar Tabakoğlu, 'The Impact of the French Revolution on the Ottoman-Spanish Relations', Turkish Studies, 3, 1 (2008). On the Italian territories, see 'Informe de la Contaduría de 9 de Julio de 1774 y respuesta del Sor Fiscal de 30 de Agosto del mismo año'.

53 On the history of Izmir and its merchant community, see Elena Frangakis-Syrett, The Commerce of Smyrna in the Eighteenth Century (1700-1820) (Athens: Centre of Asia Minor Studies, 1992), 35; Daniel Goffman, 'Izmir: From village to colonial port city', in Edhem Eldem, Daniel Goffman and Bruce Masters (eds), The Ottoman City between East and West: Aleppo, Izmir, and Istanbul (Cambridge: Cambridge University Press, 2001). For a detailed list of the American drugs sold by French merchants, see Edhem Eldem, French Trade in Istanbul in the Eighteenth Century (Leiden: Brill, 1999), 86.

54 Juan Bautista Vilar and Ramón Lourido Díaz, Relaciones entre España y el Magreb, siglos XVII y XVIII [Relations between Spain and the Maghreb, Seventeenth and Eighteenth Centuries] (Madrid: MAPFRE, 1994), 319-26. For the gifts sent to the Moroccan Court, see 'Nota de varios encargos que hace el Rey de Marruecos, [Note of Various Orders Made by the King of Morocco]' Archivo del Palacio Real, Reinados Carlos III/Legajo 197/ㄱ(1771).
} 
Royal Pharmacy every year as 'gifts' to foreign ministers, allied courts or the monarch's relations in Naples, the Ottoman Empire, Denmark and Habsburg Austria. ${ }^{55}$

The ability of the sick to utilise medical treatments is a function of both availability and price. Cinchona cost the Hôtel-Dieu de Carpentras five times as much as manna from Sicily, while other Mediterranean herbs like sage, thyme or rosemary cost a fraction of ipecacuanha or jalap. ${ }^{56}$ Wholesalers in France paid 45 livres for a pound of jalap root, forty for a pound of sarsaparilla and twenty-four for guaiacum; ipecacuanha was less costly, selling at 2 livres the pound, dragon blood at four. ${ }^{57}$ Their price was not excessive in relation to other medicinal plants 'imported from foreign nations' - fine rhubarb, from either China or India, sold at 55 livres the pound at the same time ${ }^{58}$ - but 12 to 18 livres were about one week's wages for well-off artisans in Paris in the last decades of the Ancien Régime, and some $60 \%$ of that income would have been spent on food, lodging and heat. ${ }^{59}$ They could have afforded some grams of guaiacum, jalap or sarsaparilla when exceptional circumstances demanded it, ipecacuanha or dragon blood perhaps more habitually, but they would probably have preferred home-grown herbs for the basic provisions of the domestic medicine chest. The price paid for American medicinal plants from retailers was even higher. In the electorate of Mainz, where vivax malaria was endemic, cinchona bark was unaffordable for the majority of the population. Red cinchona bark, then the most esteemed by local physicians, cost 55 gulden a pound, while bark of lesser quality still cost between 9 and 25 gulden. ${ }^{60}$ A worker's, even an artisan's, annual income then amounted to some 80 to 100 gulden at most, ${ }^{61}$ and 'only the wealthy', according to the Mainz doctor Johann C. Renard, could 'afford red cinchona' at all. 'Families without fortune, artisans, manufacturers, people with a small income or families with many children', Renard said, could not afford any kind of cinchona. ${ }^{62}$ In Europe's colonies, be it New England or Angola, many of Spanish America's medicinal plants were by all accounts yet more expensive and difficult to procure than in Europe, mostly because of tariffs or greater transportation costs. ${ }^{63}$ The fact that the ruler of Morocco should have troubled himself so far as to explicitly ask for a gift of Spanish American plant remedies - and the fact that the gifts delivered alongside them were scientific instruments and rare books -

\footnotetext{
55 In 1777 , for instance, the treasurer counted 1444 libras of select cinchona - 664kg - among the king's gifts. Miguel de Muzquiz, 'En 31 de Diciembre del año próximo anterior me pasaron el Gefe de la Real Botica, y el primer ayuda de dicho Real Oficio la cuenta adjunta del consumo que en todo el año de 1777 hubo de quina, [On 31 December of Last Year the Head of the Royal Pharmacy, and his First Aide Presented the Attached Account of Cinchona Consumed in 1777]' Archivo del Palacio Real, Reinados Carlos III/Legajo 197, 3 (1778-09-12).

56 Dubois, op. cit. (note 36).

${ }^{57}$ Février, op. cit. (note 28).

58 Ibid.

${ }^{59}$ Kaplow Jeffry, The Names of Kings: The Parisian Laboring Poor in the Eighteenth Century (New York: Basic Books, 1972), 53-4.

${ }^{60}$ Johann Claudius Renard, Die inländischen Surrogate der Chinarinde in besonderer Hinsicht auf das Kontinent von Europa [Domestic Substitutes for Peruvian Bark with Particular Regard to the European Continent] (Mainz: Kupferberg, 1809), 18.

61 Karl Härter, Policey und Strafjustiz in Kurmainz: Gesetzgebung, Normdurchsetzung und Sozialkontrolle im frühneuzeitlichen Territorialstaat [Police and Criminal Justice in the Electorate of Mainz: Legislation, the Enforcement of Norms and Social Control in the Early Modern Territorial State] (Frankfurt am Main: Klostermann, 2005), 600-1.

62 Renard, Février, op. cit. (note 60), 8.

63 On the difficulties experienced by colonial apothecaries, see Gevitz, op. cit. (note 37). For the high cost of imported medicines in Luanda, see Joseph C. Miller, Ways of Death: Merchant Capitalism and the Angolan Slave Trade, 1730-1830 (London: Currey, 1988), 286.
} 
further elucidates that Spanish American medicinal plants were neither so plentifully nor so inexpensively available even in North Africa - adjoining the Iberian Peninsula - as to make a gift of them redundant or undesirable.

Still, the consumption of tonnes of Spanish America's medicinal plants was not limited to an elite few. By the eighteenth century, 'foreign' plant-based remedies were passed on to the urban and rural poor by religious orders, private charity or, from the late eighteenth century, increasingly systematic medical relief programmes. The 'Paupers pharmacopeia' in the Hanseatic city of Hamburg, for instance, a paragon for the German territories at the time, encompassed expensive foreign drugs if they were considered indispensable or significantly more effectual than local substitutes: quassia wood, cinchona, Peruvian balsam and copaiba balsams were administered to the poor on a regular basis. ${ }^{64}$ In Bourbon Spain, in the context of a more general shift in the State's understanding of its responsibilities towards the population, the crown developed a comprehensive system of free-of-charge medical attention in the eighteenth century. This encompassed the distribution of free medicines from the Royal Pharmacy among religious convents, poorhouses, or localities afflicted by epidemics on the Iberian Peninsula and in its American empire, and Spanish American plant remedies were usually among the provisions supplied. ${ }^{65}$ Charitable endeavours by Jesuit dispensaries in Macau, Goa and Luanda $^{66}$ or British colonial administrators in India ${ }^{67}$ seem to have brought plant-based remedies from Spanish America to the poorer strata of several South and East Asian, and West African societies. The distribution of free-of-charge remedies not only extended to various societies' most destitute people but also to workers, slaves or soldiers, men and women on whose productivity or military clout masters and governments around the world relied. ${ }^{68}$ By the late eighteenth century, governments were well aware that their soldiers' health was as vital as their equipment or training for military success, and the armies of the Habsburg Empire, Great Britain, Russia, the United States and Spain received regular and concerted supplies that included Spanish American remedies such as cinchona or ipecacuanha. Further, interest in the well-being of armies even prompted medical research

64 Almuth Weidmann, Die Arzneiversorgung der Armen zu Beginn der Industrialisierung im deutschen Sprachgebiet, besonders in Hamburg [Supplying the Poor with Medicines in German-Speaking Territories during the Early Phase of Industrialization, particularly in Hamburg] (Brunswick: Deutscher Apotheker, 1982); Robert Jütte, 'Hanseatic towns: Hamburg, Bremen and Lübeck', in O.P. Grell, A. Cunningham and B. Roeck (eds), Health Care and Poor Relief in 18th and 19th Century Southern Europe (Aldershot: Ashgate, 2005).

65 On the crown's 18th century distribution of medicines among the army, convents and the court, see María Luisa de Andrés Turrión, 'Quina de la Real Hacienda para el ejército español en el siglo XVIII, [Cinchona from the Royal Treasury for the Spanish Army in the Eighteenth Century]', in José A. Armillas Vicente (ed.), Guerra y milicia en la España del X Conde de Aranda: Actas del IV Congreso de Historia Militar (Zaragoza: Aragon, Cultura y Turismo, 1998), 421. On health care and poor relief under Bourbon rule more broadly, see also Pedro Carasa, 'Welfare Provision in Castile and Madrid', in Grell, Cunningham and Roeck (eds), Health Care, op. cit. (note 64).

66 Anagnostou, op. cit. (note 28), 298.

67 The British government donated cinchona to charitable dispensaries in the nineteenth century: Richard Drayton, Nature's Government: Science, Imperial Britain and the, 'Improvement' of the World (New Haven, CT and London: Yale University Press, 2000), 230-1.

68 On slaves, see Thomson, op. cit. (note 22). On workers in Spain, see José Moñino y Redondo, Conde de Floridablanca, 'En la reparación de la Presa de la Real Acequia de Tarcana está empleado gran numero de trabajadores acosados de Tercianas, [A Large Number of the Workers Employed in Repairing the Royal Dam at Tarcana are Suffering from Tertian Fevers]', Archivo del Palacio Real, Reinados Carlos III/Legajo 197, 3 (San Ildefonso, 1788-08-28). 
on some Spanish American medicinal plants. ${ }^{69}$ Medicinal plants from Spanish America travelled the world in the eighteenth century, both geographically and socially.

\section{Accounting for the Global 'Mobility' of the Plants}

Historians of medicinal botany have often argued that the logic of the consumption of foreign plant remedies in Europe was to consume diversity - that men and women were 'simply taken with exotics' at the time. ${ }^{70}$ The dash of the 'exotic' attendant to America's medicinal plants undoubtedly accounted in some measure for their popularity, particularly in Europe and its colonies. English, Iberian and French customers alike fetishised and resorted to substances they associated with America in the eighteenth century. The provenance of foreign medicinal plants was part of their commercial appeal in Europe, and 'Peruvian balsam', jalap root, tabasco pepper and balsam of Tolu 'advertised their exotic genealogy through their very names' ${ }^{71}$ So did narratives about their 'discovery': the testimonies of 'indigenous' healers or European and Creole observations of how the 'Indians' identified and collected medicinal plants, how they applied them or prepared compounds, almost by necessity made their appearance in the period's medical advertisements, advice literature and treatises on American medicinal plants. $^{72}$ The understanding and experience of Andeans, Tupi-Guarani or Araucanians had indeed gone into identifying, collecting and preparing some of the most widely used and universally sold American remedies - the emetic properties of the dried root of ipecacuanha, ${ }^{73}$ the anti-malarial effects of cinchona ${ }^{74}$ or the cleansing potency of the greens of canchalagua. ${ }^{75}$ However, by the eighteenth century their involvement in the making of these drugs was also becoming a cultural trope, a discourse, for European naturalists, merchants and officials to capitalise on. The epistemic or social value attached to 'indigenous knowledge' in the second half of the eighteenth century remains little understood, to be sure, but there is evidence to suggest that in this period the appeal of

69 On Europe's armies, see Bruce-Chwatt and Zulueta, op. cit. (note 33), 34. In Spain, when Charles III came to the throne, he ordered that Spain's military pharmacies be supplied from Madrid's Royal Pharmacy. Andrés Turrión, 'Quina de la Real Hacienda'. During the war of independence, North American army surgeons relied on Spanish American remedies such as ipecacuanha and cinchona: Andreas-Holger Maehle, Drugs on Trial: Experimental Pharmacology and Therapeutic Innovation in the Eighteenth Century, Clio Medica/The Wellcome Institute Series in the History of Medicine (Amsterdam: Rodopi, 1999), 271.

${ }^{70}$ Londa Schiebinger, Plants and Empire (Cambridge, MA/London: Harvard University Press, 2004), 105. See also Marcy Norton, Sacred Gifts, Profane Pleasures: A History of Tobacco and Chocolate in the Atlantic World (Ithaca, NY: Cornell University Press, 2008).

71 Andrew Wear, 'The Early Modern Debate about Foreign Drugs: Localism versus Universalism in Medicine', The Lancet, 354 (1999), 149-51.

${ }^{72}$ See, for instance, William Cockburn, The Present Uncertainty in the Knowledge of Medicines in a Letter to the Physicians in the Commission for Sick and Wounded Seamen (London: Printed by R.J. for Benj. Barker and sold by J. Nutt, 1703). Preface. See also Eduardo Estrella, 'Ciencia ilustrada y saber popular en el conocimiento de la quina en el siglo XVIII, [Enlightened Science and Popular Knowledge in the Study of Cinchona in the Eighteenth Century]', in Marcos Cueto (ed.), Saberes Andinos: Ciencia y tecnología en Bolivia, Ecuador y Perú (Lima: Instituto de Estudios Peruanos, 1995), 37-57.

73 The name 'Ipecacuanha' for the period's most important emetic is a Portuguese transliteration of the TupiGuarani word for the plant, ipe-kaa-guéne, literally meaning low or creeping plant causing vomiting: the emetic properties of the shrub were well known to the indigenous population long before the Jesuits adopted it from them, though its effects against dysentery were probably not. David Greenwood, Antimicrobial Drugs: Chronicle of a Twentieth Century Medical Triumph (Oxford: Oxford University Press, 2008), 41.

74 James L.A. Webb, Humanity's Burden: A Global History of Malaria (Cambridge and New York: Cambridge University Press, 2009), 94.

75 The Spanish probably also adopted the use of canchalagua (presumably Centaurium cachanlahuen or chilensis) as a 'blood purifier' from Araucanian societies: Anagnostou, op. cit. (note 25), 78, 297. 
'Indian cures' could be relied on to advertise, popularise and sell American remedies in Mexico City, Munich and Paris alike. ${ }^{76}$ The Enlightenment's demand that science be applied, economic and vernacular accorded novel significance to the knowledge not only of Europe's rustics, its peasants and artisans, but also to that of 'illiterate knowers' outside Europe - from Arctic shamans and Finnish rune-singers to American Indians. ${ }^{77}$ Physicians and sufferers alike placed their best hope for novel remedies in 'natural men' by the end of the eighteenth century, in those society-less, uncultured creatures closer to nature than those who claimed civilisation and, later, modernity for themselves. ${ }^{78}$ The unmediated experiences of the pristine and the primitive, their peculiar intimacy with the environment, rendered them keepers of absolute truths about both nature's toxins and cures.

Were 'exoticism' or an association with American indigenity alone to account for the popularity of American medicinal plants, however, it would be hard to explain the difference in mobility of knowledge about plant-based remedies; the fact that some plant-based remedies spread so far, moving in and out of medical systems around the world, while others did not 'transfer' at all, for not all American medicinal plants were successful exports. Londa Schiebinger has pointed to how plant-based abortifacients in use in the West Indies were not adopted in European materia medica because of European physicians' objections to self-induced abortions. Schiebinger's argument about a 'rupture in the chain of knowledge' is representative of many such instances in the history of the transfer of medicinal plants. ${ }^{79}$ Spanish colonial documents abound with references to medicinal plants in use among the inhabitants of Spanish American territories that were 'neither known nor trafficked' outside their natural habitat. Officials, physicians and botanists were sometimes unable to commercialise them, and in other cases were unwilling or not interested in doing so. ${ }^{80}$ Ideological or moral tenets, as in the case of West Indian abortifacients, may certainly have influenced the inclusion or exclusion of medicinal plants in Spain's exports but so might other purposes, practicalities or criteria.

Many of these medicinal plants would have found acceptance, or not, because of their medical 'effectiveness' - though the measure and meaning of 'effectiveness' would, to be sure, not have been that of the twentieth or twenty-first centuries. The usefulness of many of the plants kept in Madrid's Royal Pharmacy derived from a medical system that fell from grace after the eighteenth century. Purgatives like Michoacán or jalap root (Ipomoea purga) were essential within the logic of humoral pathology, a system that considered illness to be the result of some disturbance in the natural balance of the humours, and the remedy to be the revulsion or derivation of humours - through bleeding, purging and emetics or sudorific substances. ${ }^{81}$ At least within that reasoning, jalap or mechoacán was 'effective': rich in glycoresins, it provokes peristaltic movements

\footnotetext{
76 Some historians have studied the appeal of 'Indian cures' among Europeans and the upper strata of North and Spanish American societies, see Joshua David Bellin, 'Taking the Indian Cure: Thoreau, Indian Medicine, and the Performance of American Culture', The New England Quarterly, LXXIX, 1 (2006), 3-36; Palmer, op. cit. (note 44), 31 .

77 Lisbet Koerner, 'Women and Utility in Enlightenment Science', Configurations 3, 2 (1995), 238. On the Creole context, see Miruna Achim, 'From Rustics to Savants: Indigenous Materia Medica in Eighteenth-Century Mexico', Studies in History and Philosophy of Biological and Biomedical Sciences, 42 (2011), 275-84.

78 Anthony Pagden, The Fall of Natural Man: The American Indian and the Origins of Comparative Ethnology (Cambridge: Cambridge University Press, 1982), 97.

79 See chapter four in Schiebinger, op. cit. (note 70).

80 'Nota de los generos medicinales que se han reconocido y vinieron de Honduras, [List of the Medicines that have been Registered and that Came from Honduras]' Archivo General de Indias, Indiferente 1547 (n.d.).

81 On humoralism, see, for instance, Vivian Nutton, 'Humoralism', in R. Porter (ed.), Companion Encyclopedia of the History of Medicine (London and New York: Routledge, 1994).
} 
in the small intestine. ${ }^{82}$ The various balsams administered in wound treatments and chest ailments - Peruvian, Tolu, dragon blood, liquidambar and copaiba - are today considered to have antiseptic and expectorant properties. ${ }^{83}$ Ipecacuanha was valued for its effectiveness against dysentery and its emetic properties in the eighteenth century and it, too, contains active principles: not only do its alkaloids cause vomiting, one of them emetine - is also an amoebicide effective against amoebic dysentery. ${ }^{84}$ Cinchona, the most popular and widely sold of Spanish America's medicinal plants in the eighteenth century, was also really effective against what contemporaries called 'intermittent fever' and what we would today call malaria: cinchona contains natural alkaloids - one of these is quinine - that kill malaria parasites during their blood stages and that are still dispensed, alongside synthetic medicines, at present. ${ }^{85}$ Several plants widely and enthusiastically consumed as medicines in the eighteenth century are today largely reduced to their effects upon our taste buds. The aphrodisiac properties of vanilla pods, ${ }^{86}$ the 'heart-warming' effects attributed to cinnamon ${ }^{87}$ or the 'stimulant' properties ascribed to tabasco pepper could not withstand the advent of 'modern' medicine but their effects upon patients' subjective well-being may well have been real. Several remedies that were not effective in the way they were proclaimed to be sooner or later fell from grace. While the total imports of medicinal plants were to multiply from the sixteenth to eighteenth centuries - the volume of purges would rise exponentially, that of balsams would augment moderately but steadily, and novel remedies like cinchona would be included - the export volume of guaiacum and sarsaparilla was smaller in the eighteenth century than it had been in the sixteenth. Twentyone tonnes of guaiacum reached Seville between 1568 and $1608,{ }^{88}$ while by the eighteenth century guaiacum imports were so negligible as to disappear from Spanish trade records. An average of 11 tonnes of sarsaparilla was imported into Spain every year between 1568 and 1620, almost thrice the amount introduced in the second half of the eighteenth century. ${ }^{89}$ Guaiacum had been hailed as an anti-syphilitic in the early sixteenth century but fell out of favour within decades: it was found by experience that people suffering from syphilis were not benefited by its administration. ${ }^{90}$ Indeed, there is no evidence to suggest they would have been: the saponins contained in guaiacum have anti-inflammatory and diaphoretic effects but no specifically anti-syphilitic ones. ${ }^{91}$ Sarsaparilla, likewise lacking

\footnotetext{
82 Rogelio Pereda-Miranda, Daniel Rosas-Ramírez and John Castañeda-Gómez, 'Resin glycosides from the morning glory family', in A.D. Kinghorn (ed.), Progress in the Chemistry of Organic Natural Products (Vienna and New York: Springer, 2010), 81.

83 On balsams, see Anagnostou, op. cit. (note 25), 313-4.

${ }^{84}$ Lee, op. cit. (note 9).

85 Webb, op. cit. (note 74), 95.

86 Donovan Stewart Correll, Native Orchids of North America North of Mexico (Stanford, CA: Stanford University Press, 1978), 161.

87 Carmen Martín Martín and José Luis Valverde, La farmacia en la América Colonial: El arte de preparar medicamentos [Pharmacy in Colonial America: The Art of Preparing Remedies] (Granada: University of Granada, 1995), 60.

${ }^{88}$ Between 1568 and 1608, some 18539 quintals of guaiacum - some 853 tonnes, 21 tonnes annually - reached Seville from Honduras, Santo Domingo, Cuba, Puerto Rico, Jamaica and Tierra Firme. Chaunu, op. cit. (note 13), 1027-9.

${ }^{89}$ Between 1568 and 1620, a total of some 614 tonnes, some 11 tonnes annually - of sarsaparilla reached Seville from the ports of New Spain, Cartagena, Honduras and Campeche and the Islands of Cuba, Santo Domingo and Puerto Rico. See table 722 in ibid.

90 See López Terrada and Pardo Tomás, op. cit. (note 9), 44. Robert Munger has studied its gradual 'fall from grace': Robert S. Munger, 'Guaiacum, the Holy Wood from the New World', Journal of the History of Medicine and Allied Sciences, IV, 2 (1949), 196-229.

${ }^{91}$ Söhner, Neue Welt und neuzeitliche Medizin, op. cit. (note 9), 41.
} 
anti-syphilitic properties, entered Spain about 1545 and physicians proclaimed it better than guaiacum but sarsaparilla, too, had apparently forfeited numerous physicians' and customers' goodwill by the eighteenth century. ${ }^{92}$ Sarsaparilla remained popular in some places - in England, for instance, it was still widely used in compound medicines in the eighteenth century ${ }^{93}$ - thus evincing how 'remedies' persisted over centuries despite their inability to 'remedy'. Still, as Harold Cook and Timothy Walker put it only recently, the view that drug treatment prior to 1800 'caused more harm than good' is in dire need of revision. ${ }^{94}$ Efficacy was, albeit gradually, becoming part of the cultural expectation of the suffering by the late eighteenth century, in conjunction with the rise of modern experimental pharmacology and the idea that a medicine should be put 'on trial' to prove its ability to produce the result it promised. ${ }^{95}$ The trade in cinchona, ipecacuanha and balsams thrived in the late eighteenth century, at least in part because these remedies kept the promises they made.

Many of the most popular plant-based remedies of the eighteenth century were those that physicians and sufferers alike had been accustomed to administering and ingesting for two centuries. Some of the earliest Iberian accounts of America's medicinal plants - Nicolás Monardes' 'Medicinal History' (1565-74), Francisco Hernández's manuscripts (written in the 1570s, published in 1651) or José de Acosta's 'Natural and Moral History of the Indies' (1590) - already described several of the remedies kept in Madrid's Royal Pharmacy by the eighteenth century: canafistola, contrayerva, mechoacán, liquidambar, the balsams of Tolu and Peru, sarsaparilla, sassafras, guaiacum, copal and dragon blood. ${ }^{96}$ Most of these plants had been readily accepted into Eurasian materia medica within years of the Spanish conquest because they had, in turn, stepped into extant circuits of Old-World trading in plants and spices. Plant-based medicines constituted a centre of gravity in the materia medica of many medical systems around the world. The preponderance of Galenic materia medica, at the heart of medicine in Europe and the Islamic world down to the nineteenth century, was plant-based, ${ }^{97}$ as was medicine in South and East Asia and pre-conquest America. ${ }^{98}$ Further, 'the search for prized medicines', their borrowing and adaptation

92 J. Worth Estes, 'The Reception of American Drugs in Europe, 1500-1650', in Simon Varey, Rafael Chabrán and Dora B. Weiner (eds), Searching for the Secrets of Nature: The Life and Works of Dr Francisco Hernández (Stanford, CA: Stanford University Press, 2000), 115.

93 Wallis, op. cit. (note 31), 34.

${ }^{94}$ Harold J. Cook and Timothy Walker, 'Circulation of Medicine in the Early Modern Atlantic World', Social History of Medicine, (2013), 1-15.

95 Maehle, Drugs on Trial: Experimental Pharmacology and Therapeutic Innovation in the Eighteenth-Century, op. cit. (note 69), ch. 1.

96 On the commercialisation and study of Spanish America's natural products in the sixteenth century, see Barrera-Osorio, Experiencing Nature: The Spanish American Empire and the Early Scientific Revolution, op. cit. (note 9), ch. 1; López Piñero and López Terrada, op. cit. (note 9).

${ }^{97}$ On the preponderance of plant-based pharmaceuticals in early modern Europe, see Paula De Vos, 'From Herbs to Alchemy: The Introduction of Chemical Medicine to Mexican Pharmacies in the Seventeenth and Eighteenth Centuries', Journal of Spanish Cultural Studies, 8, 2 (2007), 141; Martha Baldwin, 'Expanding the therapeutic canon: learned medicine listens to folk medicine', in: J. van Horn Melton (ed.), Cultures of Communication from Reformation to Enlightenment (Ashgate: Aldershot, 2002), 239-56.

98 Some of the oldest written sources in the history of Chinese, Egyptian or Indian medicine - the Pen t'sao, the Ebers Papyrus and the Vedas - list plant remedies as essential elements of their materia medica. Paul Unschuld, Medicine in China: A History of Pharmaceutics (Berkeley, Los Angeles and London: University of California Press, 1986); Judith Sumner, The Natural History of Medicinal Plants (Portland, OR: Timber Press, 2000). Hernán Cortés was impressed with Moctezuma's gardens of medicinal plants and the herb sellers lining the streets of Tenochtitlán: Estes, op. cit. (note 91), 21; Suzanne Austin Alchon, 'Tradiciones médicas nativas y resistencia en el Ecuador', in Marcos Cueto (ed.), Saberes andinos: Ciencia y tecnología en Bolivia, Ecuador y Perú (Lima: IEP, 1995), 23-4. 
across Eurasia, had long 'imposed deep patterns on world trade and the movement of peoples'. ${ }^{99}$ Several American medicinal plants had moved into Eurasian materia medica with ease and rapidity in the sixteenth century because they were varieties of plants Europeans were familiar with and had hitherto procured from China, India or the Levant. American canafistola - Cassia grandis L. - followed in the wake of Asian Cassia fistula L. ${ }^{100}$ Also, liquidambar became popular as a substitute for liquidambar from Anatolia, introduced by Byzantine physicians in the sixth and seventh centuries, while American dragon blood followed in the wake of other red resins from the Canary Islands and South Asia. ${ }^{101}$ All American 'balsams' essentially followed the lead of the antonomastic Egyptian balsam, which had been popular in Europe from the Middle Ages. ${ }^{102}$ Genera with closely related species occur in East Asia and North America because even after Laurasia, the northern subcontinent, had broken apart into North America and Eurasia 200 million years ago, the land masses were close enough for a long time to allow easy exchange of fruit and seeds. ${ }^{103}$ Other American plants moved with ease into Eurasian materia medica shortly after the conquest as surrogates for extant medicines: Spaniards arriving in the New World 'learned from the Indians' the use of American plants as purges or emetics to replace their existing humoral pharmacopeia - finding novel plants to achieve familiar effects. $^{104}$

Doctors and sufferers in East Asia, South America, Europe and North Africa alike recognised and esteemed the usefulness of an established and familiar set of medicinal plants but they also admitted novel herbs and novel effects, in particular when they were facing an unknown disease or disturbance. Circa 1800, chest pains, wounds and fevers were complaints that men and women around the world would have been familiar with by virtue of their conditio humana. Ever since human beings had developed the ability to move great distances into areas inhabited by other humans they had deposited pathogens among the newly contacted communities, aligning the infectious disease environment of societies around the world. ${ }^{105}$ Malaria parasites, for instance, had extended their ranges in parallel bands around the globe by the eighteenth century. Vivax malaria reigned in the northern reaches of Eurasia and in the British middle and northern colonies. A band of falciparum infections straddled the tropics and extended north into the southern reaches of China and south to the lower reaches of Brazil. ${ }^{106}$ The falciparum malaria burden was perhaps heaviest in tropical Africa, and after the importation of African slaves extended the epidemiological zones of tropical Africa across the South Atlantic Ocean, in the Americas. A third zone of mixed falciparum and vivax infections extended from southern China through India to the greater Mediterranean basin. ${ }^{107}$ Cinchona was re-sold into East Asia, North Africa and Europe, sought-after and much-traded, partly because it closed in on

\footnotetext{
99 Christopher A. Bayly, The Birth of the Modern World, 1780-1914: Global Connections and Comparisons (Oxford: Blackwell, 2004), 44.

100 Anagnostou, op. cit. (note 25), 313. On balsam, see López Terrada and Pardo Tomás, op. cit. (note 9), 42.

${ }^{101}$ Linda L. Barnes, Needles, Herbs, Gods, and Ghosts: China, Healing, and the West to 1848 (Cambridge, MA: Harvard University Press, 2007), 166-73.

102 Barrera-Osorio, Experiencing Nature: The Spanish American Empire and the Early Scientific Revolution, op. cit. (note 9), 12-7.

103 Sumner, The Natural History of Medicinal Plants, op. cit. (note 98), 69.

${ }^{104}$ López Terrada and Pardo Tomás, op. cit. (note 9), 43.

105 David E. Stannard, 'Disease, Human Migration, and History', in K.F. Kiple (ed.), Cambridge World History of Human Disease (Cambridge: Cambridge University Press, 1993), 35-41.

106 Webb, op. cit. (note 74), 6.

107 Ibid., 6.
} 
the disease it alone was able to remedy in the eighteenth century. Likewise, ipecacuanha: amoebic dysentery, a disease of the gastro-intestinal system that causes severe diarrhoea, was contagious, particularly in unsanitary conditions, and ipecacuanha followed its spread into British India, onto Atlantic slave ships and into the chests of military surgeons in the Napoleonic, Crimean and Boer wars. ${ }^{108}$ Venereal syphilis was mentioned for the first time in European medical and lay writings in the 1490s. It spread all over Eurasia in the course of years, making its first documented appearance in India in 1498, in Persia in 1501, in China in 1505, and in Japan in 1569. In various Eurasian medical systems remedies were believed to be found near places where the disease they cured had arisen, and guaiacum was first adopted in cases of syphilis by Portuguese, Indian, Persian and German physicians alike in the early sixteenth century because the origins of the disease were associated with Columbus' crew's return from the Americas. ${ }^{109}$ Even though differential immunity, climate conditions or divergent cultural attitudes rendered some of the world's inhabitants more vulnerable to these diseases than others, ${ }^{110}$ at the dawn of the 'first age of global imperialism' (1760-1830) societies in East Asia, South America and western Europe undeniably not only faced an unprecedentedly uniform global disease environment ${ }^{111}$ but also possessed medical systems that were more closely aligned with one another than they had ever been.

Ipecacuanha, cinchona, sarsaparilla and guaiacum were 'known and trafficked' in East Asia and Europe, in North Africa or South America, in the eighteenth century because the same illnesses and eco-pathogenic infections haunted societies around the world and because medical traditions in distant places, long aware of or related to each other by the second half of the eighteenth century, conversed and exchanged substances in their endeavours at controlling and resisting them. Medicinal plants and plant-based remedies appealed to Europeans because of their association with the exotic and the strange, because of the force of a century-long habit, and their increasingly measurable effectiveness. However, they circled the globe, because of the interconnectedness and affinity of medical systems, and disease environments, around the world by the eighteenth century.

\section{Conclusion}

A 'global history of medicine' is not, or at least not primarily, the history of different medical systems around the world but, rather, the history of how these medical systems and their materia medica have long been of consequence and related to one another. The large distances medicinal plants from Spanish America covered as they were exported in the eighteenth century, and the thrusts and forces that moved them around and about, are but one of many instances that attest to the impossibility of writing the history of eighteenthcentury medicine and medical commerce in the Iberian world, or, for that matter, in Europe, East Asia or North Africa, without reference to each other. By the late eighteenth century, the sick were consuming medicinal plants and plant-based remedies from Spanish

\footnotetext{
108 Greenwood, op. cit. (note 73), 40-1.

109 Dagmar Wujastyk, 'The Disease of the Others: Phirangaroga and its Treatment in the Bhavaprakasa' (paper presented at the Conference 'Mercury in Medicine: Fluid Economies of Knowledge and Trade', Zurich, 21 February 2013); Estes, op. cit. (note 91), 114.

110 On differential immunity see, for instance, John R. McNeill, Mosquito Empires: Ecology and War in the Greater Caribbean, 1620-1914 (Cambridge and New York: Cambridge University Press, 2010), 65.

111 Stannard, op. cit. (note 105). On the 'first global imperialism' see also Christopher A. Bayly (1998), 'The First Age of Global Imperialism, c.1760-1830', The Journal of Imperial and Commonwealth History, 26, 2, $28-47$.
} 
America in Paris, St Petersburg and Leuven, and in places like Luanda, Canton and Morocco. Some of the many reasons behind this were the charisma of the exotic and the strange, the force of a longstanding 'medical habit', as well as the widely acknowledged efficacy of these plants and it was because these places' disease environments, their medical systems and materia medica, had long become entwined and tangled. This is not to deny that attitudes towards health, patterns and possibilities of consumption, even bodily reactions to certain pathogens or remedies differed in various parts of the world, and that these differences conditioned the reception of medicinal plants. It is to say, however, that the world had long begun to become more cohesive and unified, and an altogether 'smaller place', for physicians and sufferers alike by the end of the eighteenth century. 